\title{
PROSTATE-SPECIFIC ANTIGEN (PSA) IN SERUM IN RELATION TO BLOOD LEAD CONCENTRATION AND ALCOHOL CONSUMPTION IN MEN
}

\author{
Alica PIZENT ${ }^{1}$, Božo ČOLAK ${ }^{2}$, Zorana KLJAKOVIĆ GAŠPIĆ ${ }^{1}$, and Spomenka TELIŠMAN ${ }^{1}$ \\ Institute for Medical Research and Occupational Health ${ }^{1}$, University Clinic for Diabetes, Endocrinology \\ and Metabolic Diseases "Vuk Vrhovac", Zagreb, Croatia \\ Received in July 2008 \\ Accepted in October 2008
}

\begin{abstract}
The combined influence of age, smoking, alcohol, blood lead and cadmium concentrations, and serum copper, zinc, and selenium concentrations on prostate-specific antigen (PSA) in serum was investigated in a group of 57 men aged 21 years to 40 years. The subjects had no occupational exposure to metals and no other known reasons suspected of influencing prostate function or metal metabolism. No significant correlation was found between PSA and any of the explanatory variables considered. Nevertheless, when taking into account all of the above-mentioned potentially explanatory variables, the results of stepwise multiple regression showed a significant increase in PSA with respect to an increase in blood lead, and a decrease in PSA with respect to an increase in intensity of alcohol consumption. The median and range values of blood lead concentration in the 57 men were $26.0 \mu \mathrm{g} \mathrm{L}^{-1}$ and (10.1 to 108.0) $\mu \mathrm{g} \mathrm{L}^{-1}$, respectively. These results suggest that even a low-level environmental lead exposure, common for general populations worldwide, may contribute to the risk of prostate cancer in men. The influence of lead as well as cadmium, zinc, and selenium on prostate damage and PSA should be further investigated in relatively young men for the purpose of disease prevention.
\end{abstract}

KEY WORDS: cadmium exposure, human environmental lead exposure, lifestyle factors, prostate damage, toxic and essential metals interaction.

Prostate-specific antigen (PSA), combined with digital rectal examination of the prostate, is used as an aid in the detection of prostate cancer in men. PSA is mainly synthesised in and secreted from epithelium of prostate tissue, and it correlates positively with age and prostate volume (1).

Prostate cancer is one of the most frequently diagnosed cancers in men worldwide. In Croatia in 2005 , it was diagnosed in $13 \%$ of all newly diagnosed cancers in men (2). Malignant transformation of prostate and progression of carcinoma appear to be the consequence of a complex series of initiation and promotional events under genetic and environmental influences. The most important risk factors are age, family history of disease, race and country of residence. The possible role of environmental and lifestyle factors, including smoking, alcohol consumption, and diet, has been suggested and is widely debated (3-6).

Lead $(\mathrm{Pb})$ and cadmium $(\mathrm{Cd})$ are toxic metals, both are pervasive in the human environment and accumulate in the human body over a lifetime. In spite of a decreasing trend of $\mathrm{Pb}$ exposure in Croatia (7-11) and worldwide, $\mathrm{Pb}$ toxicity remains a significant public health problem. Recent evidence has indicated that even low-to-moderate blood lead $(\mathrm{BPb})$ levels can significantly reduce human semen quality $(8,10,12)$. Pb compounds have been classified by the International Agency for Research on Cancer (IARC) as possible human carcinogens (Group 2B) 
on the basis of sufficient evidence of carcinogenicity in experimental animals, but inadequate evidence of carcinogenicity in humans (13-15). Based on the published data, $\mathrm{Pb}$ can induce DNA damage as a consequence of complex biological events, which follow one another. It is likely that the Pb-related depletion of glutathione (GSH) and/or increased production of reactive oxygen species (ROS) may be the trigger in the induction of oxidative stress that causes specific responses, depending also on the functional cellular characteristics. The lymphocytes of $\mathrm{Pb}$-exposed workers seem to respond to a chronic state of oxidative stress by mechanisms that involve downregulation of protein kinase $\mathrm{C} \alpha$, an effect that is commonly seen with other tumor promoters (16). Evaluating the possible role of environmental exposure to $\mathrm{Pb}$ as a risk factor for prostate pathology in men suffering from prostate cancer and benign prostate hyperplasia (BPH), Siddiqui et al. (17) found that $\mathrm{BPb}$ was significantly higher in prostate cancer and $\mathrm{BPH}$ cases than in control subjects. Blood levels of zinc $(\mathrm{Zn})$ and copper $(\mathrm{Cu})$ were significantly lower in prostate cancer and BPH cases than in controls. In all the three groups, a statistically significant positive correlation between $\mathrm{BPb}$ and thiobarbituric acid reactive substances (TBARS), measured as malondialdehyde, and inverse correlation between $\mathrm{BPb}$ and the antioxidant GSH level were observed after adjusting for age as a possible confounder. However, positive association between $\mathrm{BPb}$ and TBARS was relatively more pronounced in prostate cancer patients than in $\mathrm{BPH}$ and controls. These results suggest that environmental exposure of men to $\mathrm{Pb}$ may be a risk factor for prostate cancer and/or benign prostate hyperplasia, possibly through the generation of ROS and/or reducing the level of $\mathrm{Zn}$ which acts as a cellular growth protector (17). Cd has been designated as a human carcinogen (Group 1) based on its carcinogenicity to the lung (18). In several studies, $\mathrm{Cd}$ is indicated as a potential carcinogen for the human prostate $(15,19,20)$, although other studies did not find any significant association between occupational exposure to $\mathrm{Cd}$ and prostate cancer $(21,22)$. In a study of men from a Cd-polluted area in China, Zeng et al. (23) found a significant dose-response relationship between urinary $\mathrm{Cd}$ concentration and the prevalence of cases with abnormal PSA, while blood $\mathrm{Cd}$ concentration in subjects with abnormal findings on digital rectal examination of the prostate was significantly higher than in subjects with normal findings. Results of a study by van Wijngaarden et al.
(24) suggest the protective effect of an increased $\mathrm{Zn}$ intake on Cd-induced prostatic injury. Namely, these authors observed a significant positive correlation between urinary $\mathrm{Cd}$ concentration and PSA levels (after the interaction with $\mathrm{Zn}$ was taken into account) only when dietary $\mathrm{Zn}$ intake levels were low. Further investigation is needed to provide better insight into those $\mathrm{Pb}$-related and $\mathrm{Cd}$-related mechanisms of prostate cancer in men.

$\mathrm{Zn}$ and selenium (Se) are essential elements for male reproductive function $(15,25,26)$. Epidemiological studies and randomised intervention trials suggest that the risk of prostate cancer in men can be reduced by an increased intake of Se (27-29) or Zn (24). Furthermore, $\mathrm{Cu}, \mathrm{Zn}$, and $\mathrm{Se}$ are the co-factors essential for optimal activity of the antioxidant enzymes $\mathrm{Cu}, \mathrm{Zn}$-dependent intracellular superoxide dismutase (SOD) and Sedependent glutathione peroxidase (GPx), that play a key role in protecting cells against oxidative damage. It is known that oxidative stress is implicated in the pathogenesis of over 100 human diseases, including cancer. A deficiency of $\mathrm{Zn}$ and $\mathrm{Se}$, and to a lesser extent of $\mathrm{Cu}$, can have adverse consequences for disease susceptibility and maintenance of optimal health $(26,30,31) . \mathrm{Pb}$ and $\mathrm{Cd}$ can interfere with the metabolism of $\mathrm{Cu}, \mathrm{Zn}$, and Se by affecting their absorption, distribution, and bioavailability in the body; can contribute to oxidative stress; and can inhibit DNA repair $(11,15,32-35)$. On the other hand, $\mathrm{Zn}$ and $\mathrm{Se}$ may act as $\mathrm{Pb}$ and $\mathrm{Cd}$ antagonists and thus mask the $\mathrm{Pb}$-related and/or Cd-related adverse health effects (33). In the human general population, the most important sources of each of the above-mentioned metals are food, water, and air. The levels of blood $\mathrm{Pb}(\mathrm{BPb})$, blood $\mathrm{Cd}(\mathrm{BCd})$, serum $\mathrm{Cu}(\mathrm{SCu})$, serum $\mathrm{Zn}(\mathrm{SZn})$ and serum $\mathrm{Se}(\mathrm{SSe})$ are commonly used as biomarkers of metal body burden in humans, and are known to depend on age, sex, stress, dietary habits, smoking, and alcohol consumption.

Alcohol consumption has been extensively studied in relation to prostate cancer, yet findings on the direction of the association are equivocal (6). Overall results, however, indicate that alcohol may be predicted to have both adverse and beneficial effects on prostate carcinogenesis. The oxidative stress hypothesis implies that alcohol would act early in the prostate carcinogenesis pathway, and thus alcohol consumption would adversely affect the overall incidence of prostate cancer. The hormone hypothesis implies that alcohol would reduce hormonal promotion of the growth of prostate tumors. 
Namely, alcohol intake alters sex hormone levels into profiles that would be predicted to decrease the risk of prostate cancer. Whether men who drank every day (i.e. regularly) did not have an increased risk of prostate cancer because they have sustained depression of testosterone relative to oestrogen, needs further evaluation (6).

This study considers the combined influence of age, smoking, alcohol consumption, $\mathrm{BPb}, \mathrm{BCd}, \mathrm{SCu}$, $\mathrm{SZn}$, and SSe on the serum concentration of PSA in men with no occupational exposure to metals.

\section{SUBJECTS AND METHODS}

\section{Study population}

The study was carried out in 57 male subjects who had never been occupationally exposed to metals. The subjects were randomly selected among those reporting for examination in the andrology unit of the Vuk Vrhovac Clinic in Zagreb. The group contained subjects from couples with suspect infertility (who were not necessarily abnormal themselves) and voluntary candidates for semen donation for artificial insemination (who were not necessarily normal or accepted for this purpose), examined in random order under identical conditions. In order to ensure optimal methodological conditions for each subject, the examination was carried out on particular days of the week when each of the patients and semen donor candidates was equally considered for possible selection and inclusion in the study. The selection criteria were age (20 to 40 ) years; absence of a disease, condition, or exposure to physical and/or chemical factors that affect or are suspected to affect spermatogenesis or semen quality; and the absence of acute disease, or high body temperature during the preceding 4 months [period that exceeds the duration of one spermatogenesis cycle of approximately (72 \pm 9 ) days]. None of the selected subjects had been occupationally exposed to thermal, ionizing or microwave irradiation, pesticides, herbicides, organic solvents, anesthetics and vinyl chloride, or used dietary supplements containing $\mathrm{Cu}, \mathrm{Zn}, \mathrm{Se}, \mathrm{Mg}$ and $\mathrm{Fe}$, which could influence male reproductive parameters or metal metabolism. All subjects gave informed consent before inclusion in the study. The study was performed in accordance with the ethical principles for medical research involving human subjects (the World Medical Association Declaration of Helsinki, revised in October 2000) and was approved by the ethical committee of each of the two collaborating institutions in Zagreb.

A questionnaire including data on age, dietary habits, smoking, alcohol consumption, and professional and medical history was completed by a physician for each of the 57 subjects. The structured interview included questions on exposure to physical and chemical agents (based on an exposure checklist, with the names of the present and all previous organisations of employment and job titles, which were used for the individual exposure validation by a specialist in occupational health), use of dietary supplements, etc. The question with regard to dietary habits consisted of 3 options: mixed food, vegetarian with fish, or vegetarian without fish. All 57 subjects declared mixed food consumption. There were 23 smokers and 34 nonsmokers, and 24 consumers and 33 nonconsumers of alcohol. The questions with regard to the habits of smoking and alcohol consumption each consisted of 3 options: never, former, or current, including the time of cessation (year), duration period, and the habit intensity for the latter two options. For the calculations, data on the intensity of smoking (average number of cigarettes per day) and alcohol consumption (average number of "drinks", i.e. units of alcohol per week) in the previous 4 months were used, by assuming the value of zero cigarettes per day and zero "drinks" per week for nonsmokers and nonconsumers of alcohol, respectively (see Table 1).

\section{Sampling and analyses of biological specimens}

For each subject, venous blood was sampled at the Vuk Vrhovac Clinic between 08:00 h and 10:00 $\mathrm{h}$. All subjects were required to fast in the preceding $10 \mathrm{~h}$, abstain from alcohol in the preceding $24 \mathrm{~h}$, and avoid any sexual activity in the preceding 4 days. Special care was taken to avoid any contamination with metals during the blood sampling, storage, and analyses. The chemicals used for metal analyses were of analytical grade for spectroscopy (Merck, Darmstadt, Germany).

In all 57 subjects, the following measurements were performed for assessment of the metal body burden: $\mathrm{BPb}, \mathrm{BCd}, \mathrm{SCu}, \mathrm{SZn}$ and $\mathrm{SSe}$. The $\mathrm{BPb}$ and $\mathrm{BCd}$ measurements were performed by electrothermalatomic absorption spectrometry (AAS) method, essentially the same as the one described for seminal plasma $\mathrm{Pb}$ and $\mathrm{Cd}$ determination (36), controlled daily for accuracy by analyzing three reference blood samples with certified $\mathrm{BPb}$ and $\mathrm{BCd}$ values: $\mathrm{BCR}$ 
no. 194 to 196 (Community Bureau of Reference, European Commission, Brussels, Belgium). The accuracy of both $\mathrm{BPb}$ and $\mathrm{BCd}$ measurements was also controlled by the laboratory's regular participation in the National External Quality Assessment Scheme (Birmingham, UK) and our mean running variance index score (MRVIS) was consistently lower than the average MRVIS for all participants. The SCu and SZn measurements were performed by flame-AAS method (37), controlled daily for accuracy by analyzing two reference serum samples with certified $\mathrm{SCu}$ and $\mathrm{SZn}$ values: Seronorm (Nycomed Pharma, Oslo, Norway) and Second Generation (J. Versieck, Gent, Belgium). SSe was measured by electrothermal-AAS method (38), controlled daily for accuracy by analyzing two reference serum samples with certified SSe values: Seronorm (Nycomed Pharma, Oslo, Norway) and Second Generation (J. Versieck, Gent, Belgium). The accuracy of SCu, SZn, and SSe measurements was also controlled by the laboratory's regular participation in the Trace Elements External Quality Assessment Scheme (Guildford, UK) and our results were consistently categorized as being Acceptable (as opposed to Borderline or Unacceptable as the remaining two options).

PSA concentration in serum was measured by automated method using a chemiluminescence immunoassay Advia Centaur system (Siemens Medical Solutions Diagnostics, Tarrytown, NY, USA).

\section{Statistical methods}

Because of the skewed distribution of most of the measured parameters, the results are presented as range, and the $5^{\text {th }}$, the $50^{\text {th }}$ (median), and the $95^{\text {th }}$ percentile values. The significance of the difference in $\mathrm{BCd}$ and $\mathrm{BPb}$ between the subgroups of smokers and nonsmokers was calculated using the MannWhitney $U$-test $(z, p)$. Spearman's rank correlation $(r$, $p$ ) was calculated for associations between each of the measured parameters. Forward stepwise linear multiple regression was used to calculate the interrelationship of all the parameters considered possible explanatory variables (which were simultaneously introduced in the model) with respect to PSA.

\section{RESULTS}

Table 1 shows data for the variables measured in the study population. The $\mathrm{BPb}$ values indicate a low-level exposure to $\mathrm{Pb}$ in all of the 57 subjects. Exposure to $\mathrm{Cd}$ was mostly through smoking and thus the difference in $\mathrm{BCd}$ between the 23 smokers and 34 nonsmokers was highly significant $(\mathrm{z}=5.970$, $\mathrm{p}<0.0001)$. The median and range $\mathrm{BCd}$ values in these subgroups were $4.01 \mu \mathrm{g} \mathrm{L}^{-1}$ (0.25 to 6.83) $\mu \mathrm{g} \mathrm{L}^{-1}$ and $0.25 \mu \mathrm{g} \mathrm{L} \mathrm{L}^{-1}$ (0.03 to 0.97$) \mu \mathrm{g} \mathrm{L}^{-1}$, respectively. Smokers also had a significantly higher $\mathrm{BPb}$ than nonsmokers ( $\mathrm{z}=2.424, \mathrm{p}<0.02)$; the median and range $\mathrm{BPb}$ values were $37.0 \mu \mathrm{g} \mathrm{L}^{-1}$ (10.1 to 108.0) $\mu \mathrm{g} \mathrm{L}^{-1}$ and $23.8 \mu \mathrm{g} \mathrm{L}^{-1}$ (10.1 to 58.0) $\mu \mathrm{g} \mathrm{L}^{-1}$, respectively.

The results of Spearman correlation between each of the variables measured in the 57 subjects showed no significant association between PSA and any of the possible explanatory variables considered (age, smoking, alcohol, $\mathrm{BPb}, \mathrm{BCd}, \mathrm{SCu}, \mathrm{SZn}$, and $\mathrm{SSe})$. A significant positive correlation was found between $\mathrm{SCu}$ and $\mathrm{SZn}(\mathrm{r}=0.424, \mathrm{p}=0.001)$, between $\mathrm{BPb}$ and $\mathrm{BCd}(\mathrm{r}=0.417, \mathrm{p}<0.002)$, between smoking

Table 1 Descriptive data for the variables measured in 57 men with no occupational exposure to metals

\begin{tabular}{lcccc}
\hline Variable & Range & 5th & $\begin{array}{c}\text { Percentile } \\
\text { 50th } \\
\text { Median }\end{array}$ & 95th \\
\hline $\mathrm{PSA} / \mu \mathrm{g} \mathrm{L}{ }^{-1}$ & & 0.3 & 0.5 & 1.4 \\
$\mathrm{Age} /$ years & 0.2 to 1.7 & 32.4 & 38.7 \\
$\mathrm{Smoking} /$ cigarettes per day & 21.6 to 40.2 & 23.5 & 0 & 35 \\
$\mathrm{Alcohol} /$ drinks & 0 to 40 & 0 & 0 & 30 \\
$\mathrm{BPb} / \mu \mathrm{g} \mathrm{L}^{-1}$ & 0 to 35 & 0 & 26.0 & 70.0 \\
$\mathrm{BCd} / \mu \mathrm{g} \mathrm{L}^{-1}$ & 10.1 to 108.0 & 11.0 & 0.33 & 5.94 \\
$\mathrm{SCu} / \mu \mathrm{g} \mathrm{L}^{-1}$ & 0.03 to 6.83 & 0.11 & 970 & 1232 \\
$\mathrm{SZn} / \mu \mathrm{g} \mathrm{L}^{-1}$ & 698 to 1275 & 770 & 962.5 & 1158 \\
$\mathrm{SSe} / \mu \mathrm{g} \mathrm{L}^{-1}$ & 611 to 1266 & 688 & 73 & 91 \\
\hline
\end{tabular}

$B P b=$ blood lead; $B C d=$ blood cadmium; $S C u=$ serum copper; $S Z n=$ serum zinc; $S S e=$ serum selenium ${ }^{a}$ One drink $=3 \mathrm{dL}$ of beer, $1 \mathrm{dL}$ of wine, or $0.3 \mathrm{dL}$ of brandy. 
and alcohol $(\mathrm{r}=0.621, \mathrm{p}<0.0001)$, smoking and $\mathrm{BCd}$ $(\mathrm{r}=0.820, \mathrm{p}<0.0001)$, and smoking and $\mathrm{BPb}(\mathrm{r}=0.344$, $\mathrm{p}<0.009)$, and between alcohol and $\mathrm{BCd}(\mathrm{r}=0.614$, $\mathrm{p}<0.0001)$, and alcohol and $\mathrm{BPb}(\mathrm{r}=0.473, \mathrm{p}=0.0002)$. These significant correlations indicate a complex association among all these variables, suggesting the possibility that certain variables may mask a causal effect of other variables on PSA.

Table 2 shows the results of forward stepwise linear multiple regression in 57 subjects when PSA, as a dependent variable, was considered with respect to all of the following independent (explanatory) variables: age, smoking, alcohol, $\mathrm{BPb}, \mathrm{BCd}, \mathrm{SCu}, \mathrm{SZn}$, and SSe. The explanatory variables were simultaneously introduced in the model, and none of them was removed from the model throughout the stepwise procedure. Beta $(\beta)$ is the standardised regression coefficient, whereas the coefficient $B$ value relates to the units of measurement actually used for the dependent variable and independent (explanatory) variables in the equation. The advantage of $\beta$ coefficients (as compared to $\mathrm{B}$ coefficients which are not standardised) is that their magnitude allows for a direct comparison of the relative contribution of each independent variable in the prediction of the dependent variable, even for variables measured on disparate ranges or expressed in noncomparable units of measurement. The $p$-value of $\beta$ is equal to the $p$-value of $B$.

After adjusting for potentially confounding variables by multiple regression, the results (Table 2) showed a significant association between an increase in $\mathrm{BPb}$ and an increase in PSA $(\beta=0.333, \mathrm{p}=0.030)$, and between an increase in intensity of alcohol consumption (drinks per week) and a decrease in PSA $(\beta=-0.327, p=0.033)$. Exactly the same results were obtained when, in separate regression models, the multiplicative interaction term $\mathrm{BPb} * \mathrm{BCd}$ or $\mathrm{BPb}^{*}$ alcohol was introduced together with all of the remaining potentially explanatory variables considered (age, smoking, alcohol, $\mathrm{BPb}, \mathrm{BCd}, \mathrm{SCu}$, $\mathrm{SZn}$, and SSe), indicating that neither BCd nor alcohol had modified the observed significant effect of $\mathrm{BPb}$ on PSA. However, an independent effect of alcohol on PSA was observed (Table 2) that was in the opposite direction to that of $\mathrm{BPb}$ on PSA.

Essentially the same results were obtained when data for the dependent variable (PSA) included in the regression model were logarithmically $(\log )$ transformed in order to produce their normal (Gaussian) distribution. This resulted in the same explanatory variables that entered the regression equation (i.e. $\mathrm{BPb}$ and alcohol), although the corresponding $\beta$ - and $p$ values showed a slightly greater relative contribution to the effect on PSA, and a better level of significance for the given explanatory variable, as compared to those shown in Table 2 . These results were $\beta=-0.397$, $\mathrm{p}=0.009$ for alcohol, and $\beta=0.381, \mathrm{p}=0.012$ for $\mathrm{BPb}$. Exactly the same results were obtained when either $\mathrm{BPb} * \mathrm{BCd}$ or $\mathrm{BPb} *$ alcohol was introduced in the regression model together with all of the remaining potentially explanatory variables, confirming that neither $\mathrm{BCd}$ nor alcohol interacted with $\mathrm{BPb}$ and thus did not modify the observed significant effect of $\mathrm{BPb}$ on PSA.

All of the 57 men in this study had normal findings on digital rectal examination of the prostate; the absence of prostatitis and any significant increase in estimated prostate volume were found.

\section{DISCUSSION}

The $\mathrm{BPb}$ level in the study population (Table 1 ) is comparable to the levels found in adult male general population groups in many countries worldwide. In general, men have commonly higher $\mathrm{BPb}$ levels than women (15). The reported geometric mean $\mathrm{BPb}$ values for the general population groups, comprising men

Table 2 Summary of the multiple regression results for associations between prostate-specific antigen (PSA), as the dependent variable, considered with respect to all of the potentially explanatory variables (age, smoking, alcohol, $B P b, B C d$, $\mathrm{SZn}, \mathrm{SCu}$, and SSe) in 57 male subjects

\begin{tabular}{lcccc}
\hline Variable & Beta & Coefficient (B) & Standard error of B & p \\
\hline PSA & & & & \\
Intercept & & 0.4459 & 0.0836 & 0.0000 \\
BPb & 0.333 & 0.0058 & 0.0026 & 0.0305 \\
\multicolumn{1}{c}{ Alcohol } & -0.327 & -0.0109 & 0.0050 & 0.0335 \\
\hline
\end{tabular}

${ }^{a}$ Exactly the same results were obtained when, in separate regression models, the multiplicative interaction term $B P b * B C d$ or $\mathrm{BPb}$ *alcohol was introduced together with all of the above-mentioned explanatory variables. 
and women, from the United States and Japan were $28 \mu \mathrm{g} \mathrm{L}^{-1}$ (39) and $23.2 \mu \mathrm{g} \mathrm{L}^{-1}$ (40), respectively.

The $\mathrm{BCd}$ level in the study population (Table 1 ) is comparable to the levels found in general population groups in many other countries. Increased $\mathrm{BCd}$ levels in our study population can mainly be ascribed to smoking, and the relatively high $\mathrm{Cd}$ content in Croatian cigarettes. In Croatian heavy smokers, $\mathrm{BCd}$ levels of up to $13 \mu \mathrm{g} \mathrm{L}^{-1}$ were commonly found $(7,8$, 41, 42). The geometric mean $\mathrm{BCd}$ values reported for 10 countries, including Belgium, China, India, Israel, Japan, Mexico, Peru, Sweden, USA and Croatia (in former Yugoslavia), ranged from $0.2 \mu \mathrm{g} \mathrm{L}^{-1}$ (Sweden) to $1.5 \mu \mathrm{g} \mathrm{L}^{-1}$ (Belgium) for nonsmokers, and from $0.6 \mu \mathrm{g} \mathrm{L}^{-1}$ (India) to $2.8 \mu \mathrm{g} \mathrm{L}^{-1}$ (Croatia) for smokers (7), whereas those of a meta analysis in Italian subjects were $0.52 \mu \mathrm{g} \mathrm{L}^{-1}$ for nonsmokers and $1.47 \mu \mathrm{g} \mathrm{L}^{-1}$ for smokers (43). The BCd levels for nonsmokers in this study [median: $0.25 \mu \mathrm{g} \mathrm{L}^{-1}$, range: (0.03 to $\left.0.97) \mu \mathrm{g} \mathrm{L}^{-1}\right]$ and in our previous studies $(7,8,41$, $42,44)$ are comparable to or even lower than those in other countries.

The levels of $\mathrm{SCu}, \mathrm{SZn}$, and SSe in the study population (Table 1) are comparable to those for healthy adult general population groups in many other countries, although the range of published values is relatively wide. For example, the reported range for $\mathrm{SCu}$ was (600 to 1760$) \mu \mathrm{g} \mathrm{L}^{-1}$ in Italian subjects (45) and (585 to 2027) $\mu \mathrm{g} \mathrm{L}^{-1}$ in German subjects (46), and that for SZn was (540 to 1510$) \mu \mathrm{g} \mathrm{L}^{-1}$ in Italian subjects (45) and (608 to 1510$) \mu \mathrm{g} \mathrm{L}^{-1}$ in German subjects (46). Variations in SSe levels are particularly pronounced, both between different countries and within some countries such as the United States and China, which is mainly because of the large differences in Se concentration in soil (47); among 20 countries considered, the lowest average SSe values $\left(<80 \mu \mathrm{g} \mathrm{L}^{-1}\right)$ are found in New Zealand and generally in the eastern European countries, whereas the highest average SSe values have been reported from the seleniferous regions in the United States $\left(198 \mu \mathrm{g} \mathrm{L}^{-1}\right)$ and China $\left(490 \mu \mathrm{g} \mathrm{L}^{-1}\right)$.

Epidemiological studies of combined exposure to various metals that may influence individual susceptibility to adverse health effects are generally lacking. Similarly to our previous findings in men (9-11, 42, 44), significant correlations were found between smoking habits, alcohol consumption, $\mathrm{BPb}$, and $\mathrm{BCd}$ in the group of men in this study. With regard to the hypothesis that $\mathrm{Pb}$ and/or Cd adversely affect prostate function and may also influence PSA level in men, these variables may be both potential confounders and risk factors.

After adjusting for a possible influence on PSA of each of the explanatory variables considered in the study population, the multiple regression results (Table 2) showed a small, albeit significant BPbrelated increase in PSA. It is important to note that the study population consisted of relatively young men [age median: 32 years, range: (21 to 40 ) years] known to be at lower risk of prostate cancer compared to elderly men. Furthermore, the $\mathrm{BPb}$ values in the study population indicate a low-level exposure to $\mathrm{Pb}$ (Table 1) with regard to the currently acceptable $\mathrm{BPb}$ limit of $100 \mu \mathrm{g} \mathrm{L}^{-1}$ for the general population, including children, who are particularly susceptible to $\mathrm{Pb}$ toxicity (15).

In addition to direct toxicity of $\mathrm{Pb}$ on the prostate secretory function in men, as indicated by a significant $\mathrm{Pb}$-related decrease in seminal plasma concentrations of $\mathrm{Zn}$, acid phosphatase, and citric acid $(8,10,25,48)$, there are two plausible mechanisms for $\mathrm{Pb}$-induced prostate damage that may ultimately progress into prostate cancer. One is related to the role of $\mathrm{Pb}$ through oxidative stress $(15,17,33,35,49,50)$. The other concerns a significant $\mathrm{Pb}$-related increase in serum testosterone, observed at low-to-moderate levels of chronic exposure to $\mathrm{Pb}$ in men $(8,10)$. This may have implications on the initiation and development of prostate cancer, because testosterone is known to augment the progress of prostate cancer in its early stages. It is interesting to note that the highest prevalence of prostate cancer in the general population of men has been reported for African Americans, known to commonly have relatively higher BPb levels than other ethnic groups in the United States.

Published evidence on the possible association between an increased risk of prostate cancer and $\mathrm{Pb}$ and/or $\mathrm{Cd}$ in occupationally exposed men is inconclusive (15). This may partly be explained by the fact that in many circumstances an increased exposure to these toxic metals is combined. Furthermore, occupational and environmental exposures to each of these metals are usually combined with exposure to the essential metal $\mathrm{Zn}$ that can act as an antagonist of the $\mathrm{Pb}$-related and $\mathrm{Cd}$-related reproductive toxicity (15, $25,33)$. Thus it is important to simultaneously measure biomarkers of $\mathrm{Pb}, \mathrm{Cd}$, and $\mathrm{Zn}$ body burden and to control and adjust for each other, when evaluating the effect of any of these metals on PSA and prostate function in men. 
With regard to the observed significant inverse association between PSA and intensity of alcohol consumption (drinks per week) after adjusting for potentially confounding variables by multiple regression (Table 2), it is important to note that alcohol consumption significantly positively correlated with $\mathrm{BPb}$ in the study population $(\mathrm{r}=0.473, \mathrm{p}=0.0002)$. This association between alcohol consumption and $\mathrm{BPb}$ is common in humans $(9-11,44,51)$ because alcoholic beverages contain an appreciable amount of $\mathrm{Pb}$, and also because ethanol metabolism alters redox potential in the body and thus can mobilise the biologically inert fraction of accumulated $\mathrm{Pb}$ from the bones into the peripheral blood. Therefore, it seems possible that some of the reported alcohol-induced adverse effects on prostate carcinogenesis in men, reviewed by Platz et al. (6), may in fact be causally related to $\mathrm{Pb}$, since those studies did not address $\mathrm{Pb}$ as a possible confounder. Furthermore, the oxidative stress hypothesis related to the effect of alcohol on prostate carcinogenesis (6) seems not to be plausible in view of decreased (rather than increased) erythrocyte lipid peroxidation in alcohol drinkers compared to controls, which was particularly evident in subjects who consumed more than $140 \mathrm{~g}$ of alcohol per day (52). However, the influence of alcohol consumption on PSA and prostate cancer in men still appears equivocal. For further elucidation, more studies on a large number of men should be done by performing a thorough control and adjustment for many potential confounders, including $\mathrm{BPb}$ in particular.

In conclusion, after adjusting for potentially confounding variables by multiple regression, this study has shown a significant positive association between PSA and $\mathrm{BPb}$. This was observed in relatively young men at a low-level environmental $\mathrm{Pb}$ exposure common for general populations worldwide. With regard to the possibly related risk of prostate cancer, the influence of $\mathrm{Pb}, \mathrm{Cd}, \mathrm{Zn}$, and $\mathrm{Se}$ on prostate damage and PSA should be further investigated in relatively young men for the purpose of disease prevention.

\section{Acknowledgement}

This study is a part of the research project "Reproductive health effects of toxic and essential metals in men" sponsored by the Croatian Ministry of Science, Education and Sports (grant no. 022-0222411-2408).

\section{REFERENCES}

1. Collins GN, Lee RJ, McKelvie GB, Rogers AC, Hehir M. Relationship between prostate specific antigen, prostate volume and age in the benign prostate. Br J Urol 1993;71:44550.

2. Hrvatski zavod za javno zdravstvo, Služba za epidemiologiju, Registar za rak. Incidencija raka u Hrvatskoj 2005 [Croatian Health Care Institute Cancer Registry. Cancer incidence in Croatia in 2005, in Croatian]. Bilten 2007;(30).

3. Haas GP, Sakr WA. Epidemiology of prostate cancer. CA Cancer J Clin 1997;47:273-87.

4. Pienta KJ, Esper PS. Risk factors for prostate cancer. Ann Intern Med 1993;118:793-803.

5. Giovannucci E, Liu Y, Platz EA, Stampfer MJ, Willett WC. Risk factors for prostate cancer incidence and progression in the health professionals follow-up study. Int J Cancer 2007;121:1571-8.

6. Platz EA, Leitzmann MF, Rimm EB, Willett WC, Giovannucci E. Alcohol intake, drinking patterns, and risk of prostate cancer in a large prospective cohort study. Am J Epidemiol 2004;159:444-53.

7. Vahter M, editor. Assessment of human exposure to lead and cadmium through biological monitoring. Stockholm: National Swedish Institute of Environmental Medicine and Department of Environmental Health, Karolinska Institute; 1982.

8. Telišman S, Cvitković P, Jurasović J, Pizent A, Gavella M, Ročić B. Semen quality and reproductive endocrine function in relation to biomarkers of lead, cadmium, zinc, and copper in men. Environ Health Perspect 2000;108:45-53.

9. Telišman S, Jurasović J, Pizent A, Cvitković P. Blood pressure in relation to biomarkers of lead, cadmium, copper, zinc, and selenium in men without occupational exposure to metals. Environ Res 2001;87:57-68.

10. Telišman S, Čolak B, Pizent A, Jurasović J, Cvitković P. Reproductive toxicity of low-level lead exposure in men. Environ Res 2007;105:256-66.

11. Pizent A, Jurasović J, Telišman S. Serum calcium, zinc, and copper in relation to biomarkers of lead and cadmium in men. J Trace Elem Med Biol 2003;17:199-205.

12. Hernández-Ochoa I, García-Vargas G, López-Carrillo L, Rubio-Andrade M, Morán-Martínez J, Cebrián ME, Quintanilla-Vega B. Low lead environmental exposure alters semen quality and sperm chromatin condensation in northern Mexico. Reprod Toxicol 2005;20:221-8.

13. International Agency for Research on Cancer (IARC). IARC Monographs on the Evaluation of Carcinogenic Risks to Humans Overall Evaluations of Carcinogenicity: An Updating of IARC Monographs Vol 1-42. Supplement 7. Lyon: IARC; 1987.

14. Vainio H. Lead and cancer-association or causation. Scand J Work Environ Health 1997;23:1-3.

15. Nordberg GF, Fowler BA, Nordberg M, Friberg LT, editors. Handbook on the toxicology of metals. Amsterdam: Academic Press Elsevier; 2007.

16. Fracasso ME, Perbellini L, Soldà S, Talamini G, Franceschetti P. Lead induced DNA strand breaks in lymphocytes of exposed workers: role of reactive oxygen species and protein kinase C. Mutat Res 2002;515:159-69.

17. Siddiqui MK, Srivastava S, Mehrotra PK. Environmental exposure to lead as a risk for prostate cancer. Biomed Environ Sci 2002;15:298-305.

18. International Agency for Research on Cancer (IARC). IARC Monographs on the evaluation of carcinogenic risks 
to humans. Beryllium, cadmium, mercury, and exposures in the glass manufacturing industry. Vol 58. Lyon: IARC; 1993.

19. Ross RK, Shimizu H, Paganini-Hill A, Honda G, Henderson BE. Case-control studies of prostate cancer in blacks and whites in southern California. J Natl Cancer Inst 1987;78:869-74.

20. Van der Gulden, Kolk JJ, Berbeek AL. Work environment and prostate cancer risk. Prostate 1995;27:250-7.

21. Sorahan T, Waterhouse JAH. Mortality study of nickelcadmium battery workers by the method of regression models in life tables. Br J Ind Med 1983;40:293-300.

22. Armstrong BG, Kazantzis G. The mortality of cadmium workers. Lancet 1983;1:1425-7.

23. Zeng X, Jin T, Jian X, Kong Q, Ye T, Nordberg GF. Effects on the prostate of environmental cadmium exposure - a crosssectional population study in China. Biometals 2004; 17:55965.

24. van Wijngaarden E, Singer EA, Palapattu GS. Prostatespecific antigen levels in relation to cadmium exposure and zinc intake: results from the 2001-2002 National Health and Nutrition Examination Survey. Prostate 2008;68:122-8.

25. Apostoli P, Telišman S, Sager PR. Reproductive and developmental toxicity of metals. In: Nordberg GF, Fowler BA, Nordberg M, Friberg LT, editors. Handbook on the toxicology of metals. Amsterdam: Academic Press Elsevier; 2007. p. 213-49.

26. Rayman MP. The importance of selenium to human health Lancet 2000;356:233-41.

27. Brooks JD, Metter EJ, Chan DW, Sokoll LJ, Landis P, Nelson WG, Muller D, Andres R, Carter HB. Plasma selenium level before diagnosis and the risk of prostate cancer development J Urol 2001;166:2034-8.

28. Hoenjet KM, Dagnelie PC, Delaere KP, Wijckmans NE, Zambon JV, Oosterhof GO. Effect of a nutritional supplement containing vitamin $\mathrm{E}$, selenium, vitamin $\mathrm{C}$ and coenzyme Q10 on serum PSA in patients with hormonally untreated carcinoma of the prostate: a randomised placebo-controlled study. Eur Urol 2005;47:433-9.

29. Clark LC, VB, Krongrad A, Combs GF Jr, Turnbull BW, Slate EH, Witherington R, Herlong JH, Janosko E, Carpenter D, Borosso C, Falk S, Rounder J. Decreased incidence of prostate cancer with selenium supplementation: results of a double-blind cancer prevention trial. Br J Urol 1998;81:7304.

30. Walsh CT, Sandstead HH, Prasad AS, Newberne PM, Fraker PJ. Zinc: Health effects and research priorities for the 1990s. Environ Health Perspect 1994;102(Suppl. 2):5-46.

31. Arthur JR, McKenzie RC, Beckett GJ. Selenium in the immune system. J Nutr 2003;133(5 Suppl 1):1457S-9S

32. Nordberg GE. Factors influencing metabolism and toxicity of metals: a consensus report. Environ Health Perspect 1978;25:3-41.

33. Telišman $\mathrm{S}$. Interactions of essential and/or toxic metals and metalloids regarding interindividual differences in susceptibility to various toxicants and chronic diseases in man. Arh Hig Rada Toksikol 1995;46:459-76.

34. Hartwig A. Role of DNA repair inhibition in lead- and cadmium-induced genotoxicity: a review. Environ Health Perspect 1994;102(Suppl. 3):45-50.

35. Jurasović J, Pizent A, Telišman S. Serum selenium in relation to biomarkers of lead in men. In: Roussel AM, Anderson RA,
Favrier AE, editors. Trace elements in man and animals 10 . New York: Kluwer Academic/Plenum Publishers; 2000. p. 675-8.

36. Jurasović J, Telišman S. Determination of lead and cadmium in human seminal fluid by electrothermal atomic absorption spectrometry. J Anal At Spectrom 1993;8:419-25.

37. Pizent A, Telišman S. Analysis of reference materials for serum copper and zinc by flame AAS. At Spectrosc 1996;17:88-91.

38. Gammelgaard B, Jøns O. Comparison of palladium chemical modifiers for the determination of selenium in plasma by Zeeman-effect background corrected electrothermal atomic absorption spectrometry. J Anal At Spectrom 1977;12:46570.

39. Brody DJ, Pirkle JL, Kramer RA, Flegal KM, Matte TD, Gunther EW, Paschal DC. Blood lead levels in the US population. Phase 1 of the Third National Health and Nutrition Examination Survey (NHANES III, 1988 to 1991). J Am Med Assoc 1994;272:277-83.

40. Watanabe T, Nakatsuka H, Shimbo S, Iwami O, Moon CS, Zhang ZW, Iguchi $\mathrm{H}$, Ikeda M. Reduced cadmium and lead burden in Japan in the past 10 years. Int Arch Occup Environ Health 1996;68:305-14.

41. Telišman S, Azarić J, Prpić-Majić D. Cadmium in blood as an indicator of integrated exposure to cadmium in the urban population. Bull Environ Contam Toxicol 1986;36:491-5.

42. Telišman S, Jurasović J, Pizent A, Cvitković P. Cadmium in the blood and seminal fluid of nonoccupationally exposed adult male subjects with regard to smoking habits. Int Arch Occup Environ Health 1997;70:243-8.

43. Alessio L, Apostoli P, Forni A, Toffoletto F. Biological monitoring of cadmium exposure - an Italian experience. Scand J Work Environ Health 1993;19(Suppl. 1):27-33.

44. Jurasović J, Cvitković P, Pizent A, Čolak B, Telišman $\mathrm{S}$. Semen quality and reproductive endocrine function with regard to blood cadmium in Croatian male subjects. Biometals 2004;17:735-43.

45. Minoia C, Sabbioni E, Apostoli P, Pietra R, Pozzoli L, Gallorini M, Nicolaou G, Alessio L, Capodaglio E. Trace element reference values in tissues from inhabitants of the European Community. I. A study of 46 elements in urine, blood and serum of Italian subjects. Sci Total Environ 1990;95:89-105.

46. Rükgauer M, Klein J, Kruse-Jarres JD. Reference values for the trace elements copper, manganese, selenium, and zinc in the serum/plasma of children, adolescents, and adults. J Trace Elem Med Biol 1997;11:92-8.

47. Alfthan G, Neve J. Selenium intakes and plasma selenium levels in various populations. In: Kumpulainen JT, Salonen JT, editors. Natural antioxidants and food quality in atherosclerosis and cancer prevention. Cambridge: The Royal Society of Chemistry; 1996. p. 161-7.

48. Wildt K, Eliasson R, Berlin M. Effects of occupational exposure to lead on sperm and semen. In: Clarkson TW, Nordberg GF, Sager PR, editors. Reproductive and developmental toxicity of metals. New York (NY): Plenum Press, 1983. p. 279-300.

49. Saxena G, Flora SJS. Lead-induced oxidative stress and hematological alterations and their response to combined administration of calcium disodium EDTA with a thiol chelator in rats. J Biochem Mol Toxicol 2004;18:221-33.

50. Pillai A, Gupta S. Antioxidant enzyme activity and lipid 
peroxidation in liver of female rats co-exposed to lead and cadmium: effects of vitamin $\mathrm{E}$ and $\mathrm{Mn}^{2+}$. Free Radic Res 2005;39:707-12.

51. Pizent A, Jurasović J, Telišman S. Blood pressure in relation to dietary calcium intake, alcohol consumption, blood lead, and blood cadmium in female nonsmokers. J Trace Elem Med Biol 2001;15:123-30.
52. Akkus I, Gultekin F, Akoz M, Caglayan O, Bahcaci S, Can UG, Ay M, Gurel A. Effect of moderate alcohol intake on lipid peroxidation in plasma, erythrocyte and leukocyte and on some antioxidant enzymes. Clin Chim Acta 1997;266:141-7. 
Sažetak

\section{PROSTATNI SPECIFIČNI ANTIGEN (PSA) U SERUMU U ODNOSU NA KONCENTRACIJU OLOVA U KRVI I KONZUMIRANJE ALKOHOLA U MUŠKARACA}

Zajednički utjecaj dobi, pušenja, alkohola, koncentracija olova i kadmija u krvi te koncentracija bakra, cinka i selenija u serumu na prostatni specifični antigen (PSA) u serumu istražen je u skupini od 57 muškaraca dobi od 21 do 40 godina. Ispitanici nisu bili profesionalno izloženi metalima niti su imali druge poznate razloge za sumnju o mogućem utjecaju na funkciju prostate ili na metabolizam metala. Nije nađena značajna korelacija između PSA i bilo koje od razmatranih uzročnih varijabla. Međutim, nakon što su uzete u obzir sve navedene potencijalno uzročne varijable, rezultati postupne višestruke regresije pokazali su značajan porast PSA u odnosu na porast olova u krvi, kao i značajno sniženje PSA u odnosu na porast intenziteta konzumiranja alkohola (broj jedinica alkohola na tjedan). Vrijednosti medijana i raspona koncentracije olova u krvi u toj skupini muškaraca bile su $26,0 \mu \mathrm{g} \mathrm{L}^{-1}$ te $10,1 \mu \mathrm{g} \mathrm{L}^{-1}$ do $108,0 \mu \mathrm{g} \mathrm{L}^{-1}$. Rezultati upućuju na mogućnost da čak i niska razina izloženosti olovu iz okoliša, uobičajena za opće populacije diljem svijeta, može pridonijeti opasnosti od raka prostate u muškaraca. Potrebno je daljnje istraživanje utjecaja olova i također kadmija, cinka i selenija na oštećenje prostate i na PSA u relativno mladih muškaraca u svrhu prevencije bolesti.

KLJUČNE RIJEČI: interakcija toksičnih i esencijalnih metala, čimbenici načina života, čovjekova izloženost olovu iz okoliša, izloženost kadmiju, oštećenje prostate

\section{CORRESPONDING AUTHOR:}

Alica Pizent

Institute for Medical Research and Occupational Health P.O. Box 291, HR-10001 Zagreb, Croatia

E-mail:apizent@imi.hr 